\title{
Aktivitas Antibakteri Komposit Ag - Tulang Ikan Cakalang pada Staphylococcus aureus
}

\author{
Elmi C.J. Pandelakia*, Audy D. Wuntua, Henry F. Aritonanga \\ aJurusan Kimia, FMIPA, Unsrat, Manado
}

\begin{tabular}{l} 
K A T A K U N C I \\
\hline Ikan Cakalang \\
Hidroksiapatit alami \\
Perak \\
Antibakteri
\end{tabular}

\begin{abstract}
A B S T R A K
Telah dilakukan penelitian untuk mengetahui aktivitas antibakteri komposit Ag - tulang ikan cakalang pada Staphylococcus aureus. Tulang ikan cakalang dikeringkan, dihaluskan dan diayak 65 mesh kemudian dicampur dengan larutan perak nitrat dengan perbandingan $\mathrm{Ag}$ : tulang ikan sebesar $5: 1,4: 2$, dan $3: 3$ selama 1 jam pada suhu $70{ }^{\circ} \mathrm{C}$. Campuran kemudian di kalsinasi pada suhu $650{ }^{\circ} \mathrm{C}$ selama 2 jam. Uji aktivitas antibakteri dari komposit yang terbentuk dikerjakan dengan metode sumuran menggunakan bakteri Staphylococcus aureus. Hasil penelitian menunjukkan aktivitas antibakteri pada perbandingan 4:2 dengan lama waktu pencampuran 1 jam paling efektif untuk menghambat bakteri Staphylococcus aureus dengan diameter zona hambat sebesar $25 \mathrm{~mm}$. Penelitian ini menunjukkan valorisasi dari produk sampingan industri makanan seperti tulang ikan untuk membentuk bahan yang berpotensi berharga sebagai bahan implan tulang yang resistan terhadap infeksi bakteri.
\end{abstract}

K E Y W OR D S

Skipjack Fish, Natural hydroxyapatite Silver

Antibacterial

\begin{abstract}
A B S T R A C T
Research has been conducted to determine the antibacterial activity of $\mathrm{Ag}$ - Bone skipjack tuna toward Staphylococcus aureus. Skipjack tuna bone dried, mashed and sifted 65 mesh then mixed with silver nitrate solution with a ratio of $\mathrm{Ag}$ : fish bones of $5: 1,4: 2$, and $3: 3$ for 1 hour at $70{ }^{\circ} \mathrm{C}$. The mixture was then calcined at $650{ }^{\circ} \mathrm{C}$ for 2 hours. Antibacterial activity test of the composites formed was done by the method of wells using the bacteria Staphylococcus aureus. The results showed that antibacterial activity at a ratio of 4: 2 with a one-hour mixing time was most effective for inhibiting Staphylococcus aureus bacteria with a $25 \mathrm{~mm}$ inhibition zone diameter. This study shows the valorization of food industry byproducts such as fish bones to form potentially valuable ingredients for bone implants resistant to bacterial infections.
\end{abstract}

TERSEDIA ONLINE

01 Agustus 2018

1. Pendahuluan

Hidroksiapatit merupakan contoh dari biokeramik bioaktif yang biasanya digunakan untuk merekonstruksi bagian tulang dan gigi yang terkena penyakit. Bahan tulang pengganti tradisional yang sudah umum seperti autografts, allografts dan xenografts, tidak bertahan lama sehingga menyebabkan resiko infeksi mikroorganisme. Salah satu penyebab infeksi adalah bakteri. Bakteri patogen lebih berbahaya dan menyebabkan infeksi baik secara sporadik maupun endemik, antara lain Staphylococcus aureus (Djide \& Sartini, 2008).
Diantara berbagai nanopartikel logam, nanopartikel perak (Ag) telah diketahui memiliki khasiat penghambatan dan antimikroba yang baik terhadap bakteri, virus, dan mikroorganisme eukariotik lainnya (Kim et al., 2007). Dalam beberapa kasus ion Ag diperkenalkan di kisi hidroksiapatitp sebagai dopan (Stanić et al., 2011), dan disisi lain perak hadir sebagai $\mathrm{Ag}_{3} \mathrm{PO}_{4}$ (Piccirillo et al., 2014).

Tulang ikan menjadi salah satu alternatif sumber alami hidroksiapatit sekitar 60 - 70\%. Dalam penelitian ini tulang ikan cakalang yang

*Corresponding author: Jurusan Kimia FMIPA UNSRAT, Jl. Kampus Unsrat, Manado, Indonesia 95115; Email address: emipandelaki01@gmail.com Published by FMIPA UNSRAT (2018) 
diketahui mengandung hidroksiapatit disintesis menggunakan perak nitrat dan di uji aktivitas antibakterinya terhadap bakteri S. aureus.

\section{Material dan Metode}

\section{Alat dan Bahan}

Peralatan yang digunakan adalah tanur, oven, inkubator, autoklaf, mikropipet, dan mistar berskala.

Bahan-bahan yang digunakan adalah tulang ikan cakalang, bakteri uji (Staphylococcus aureus), tablet Ciprofloxacin 500 mg, Nutrient Agar (NA), $\mathrm{NaCl} 0,9 \%, \mathrm{AgNO}_{3}$, phosphate buffer saline (PBS),

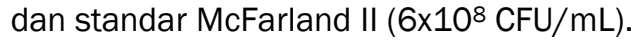

\section{Preparasi Tulang Ikan Cakalang}

Preparasi ini mengikuti metode dari Piccirillo et al. (2014), yang telah dimodifikasi. Preparasi bertujuan untuk menghilangkan sisa-sisa daging yang masih menempel. Preparasi diawali dengan mengkukus tulang ikan sebanyak $1 \mathrm{~kg}$. Pengukusan dilakukan pada suhu $80^{\circ} \mathrm{C}$ selama 30 menit. Tulang ikan dijemur di bawah sinar matahari selama 18 jam. Tulang ikan yang sudah dijemur di keringkan lebih lanjut kedalam oven dengan suhu $45-48{ }^{\circ} \mathrm{C}$ selama 72 jam. Setelah dioven tulang ikan kemudian dilakukan penepungan dengan cara ditumbuk dan di blender dan di ayak sampai halus.

\section{Sintesis Ag - tulang ikan cakalang}

Sintesis Ag - tulang ikan cakalang meggunakan metode Piccirillo et al. (2014), yang telah dimodifikasi. Tulang ikan yang sudah diolah menjadi tepung, dicampur ke dalam larutan $\mathrm{AgNO}_{3}$ (Rasio molar perak dan HAp yang digunakan adalah 5:1; 4:2 ; dan 3:3 untuk Ag : HAp). Konsentrasi HAp dihitung dengan asumsi bahwa $65 \%$ dari berat tulang adalah HAp. Larutan dengan tulang ikan dan perak nitrat diaduk pada temperature $70^{\circ} \mathrm{C}$ selama 1 jam menggunakan magnetik stirer. Selanjutnya campuran larutan tersebut dikalsinasi pada temperatur $650^{\circ} \mathrm{C}$ selama 2 jam.

\section{Uji Aktivitas Antibakteri Sterilisasi Alat (Lay dan Hastowo, 1992)}

Alat-alat yang digunakan dalam penelitian aktivitas antibakteri ini disterilkan terlebih dahulu. Alat-alat gelas disterilkan dalam oven pada suhu $170^{\circ} \mathrm{C}$ selama \pm 2 jam, jarum ose dan pinset dibakar dengan pembakaran diatas api langsung dan media disterilkan dalam autoklaf pada suhu $121^{\circ} \mathrm{C}$ selama 15 menit.

\section{Pembuatan Larutan Kontrol Positif}

Kontrol positif dibuat dari sediaan obat tablet Ciprofloxacin $500 \mathrm{mg}$. Satu tablet Ciprofloxacin digerus, lalu ditimbang dan disetarakan dengan 500 mg. Kemudian serbuk Ciprofloxacin sebanyak 50 mg dilarutkan dalam $50 \mathrm{~mL}$ larutan PBS untuk memperoleh larutan Ciprofloxacin $50 \mu \mathrm{g} / 50 \mu \mathrm{L}$. Selanjutnya diencerkan dengan cara diambil $1 \mathrm{~mL}$ dari larutan Ciprofloxacin $50 \mu \mathrm{g} / 50 \mu \mathrm{L}$ dan digenapkan sampai $10 \mathrm{~mL}$ dengan larutan PBS sehingga didapat larutan kontrol positif dengan konsentrasi $5 \mu \mathrm{g} / 50 \mathrm{~mL}$

\section{Pembuatan Larutan Uji (Nirmala et al., 2011)}

Dibuat larutan uji dengan melarutkan komposit HAp - Ag dengan lama waktu stirrer 1 jam dengan perbandingan $5: 1 ; 4: 2$; dan 3:3 (A1, A2 dan A3) dengan phosphate buffer saline (PBS; 1 g HAp - Ag dalam $2 \mathrm{~mL}$ PBS).

\section{Pembuatan Media Dasar dan Media Pembenihan (Lay, 1994)}

Media dasar dibuat dengan cara ditimbang Nutrient Agar (NA) sebanyak 2,3 gram, lalu dilarutkan dalam $100 \mathrm{~mL}$ aquades (23 g/1000 mL) menggunakan erlenmeyer. Sedangkan media pembenihan dibuat dengan cara ditimbang 5,75 gram NA, lalu dilarutkan dalam $250 \mathrm{~mL}$ aquades (23 $\mathrm{g} / 1000 \mathrm{~mL}$ ) menggunakan erlenmeyer. Setelah itu, masing-masing media dihomogenkan dengan stirer diatas penangas air sampai mendidih. Media media yang sudah homogen ini disterilkan dalam outoklaf pada suhu $121^{\circ} \mathrm{C}$ selama 15 menit, kemudian didinginkan sampai suhu $\pm 45-50{ }^{\circ} \mathrm{C}$. Media dasar dan media pembenihan digunakan dalam pembuatan media pengujian sebagai lapisan dasar dan lapisan kedua.

\section{Pembuatan Suspensi Bakteri Uji (Mpila et al., 2012)}

Bakteri uji yang telah diinokulasi diambil dengan kawat ose steril lalu disuspensikan kedalam tabung yang berisi $2 \mathrm{~mL}$ larutan $\mathrm{NaCl} 0,9 \%$ hingga di peroleh kekeruhan yang sama dengan standar kekeruhan Iarutan Mc. Farland. Perlakuan yang sama dilakukan pada setiap jenis bakteri uji.

Pembuatan Media Pengujian (Mpila et al., 2012)

Pada pembuatan media pengujian untuk tiga perbandingan sampel dengan lama waktu stirrer 1 jam, lapisan dasar dibuat dengan menuangkan masing-masing $15 \mathrm{~mL}$ NA dari media dasar ke dalam 6 cawan petri, lalu dibiarkan sampai memadat. Setelah memadat, pada permukaan lapisan dasar diletakkan 5 pencadang baja yang diatur sedemikian rupa jaraknya agar daerah pengamatan tidak saling bertumpuh. Kemudian, suspensi bakteri dicampurkan ke dalam media pembenihan NA. Setelah itu, dituangkan $15 \mathrm{~mL}$ campuran suspensi dan media pembenihan tersebut ke dalam tiap cawan petri yang diletakkan pencadang sebagai lapisan kedua. Selanjutnya, pencadang diangkat secara aseptik dari cawan petri, sehingga akhirnya terbentuklah sumur-sumur yang akan digunakan dalam uji antibakteri. Prosedur yang sama dilakukan untuk pengujian dua perbandingan sampel dengan lama waktu stirrer 24 jam.

Uji Aktivitas Antibakteri secara In-vitro

Uji Aktivitas Antibakteri secara In-vitro meggunakan metode Mpila et al. (2012), yang telah dimodifikasi. Larutan uji dengan berbagai perbandingan (A1, A2, dan A3), larutan PBS sebagaii kontrol negatif; larutan Ciprofloxacin sebagai kontrol positif, masing-masing diteteskan pada sumur yang berbeda sebanyak $50 \mu \mathrm{L}$. Kemudian cawan petri diinkubasi dalam inkubator pada suhu $37^{\circ} \mathrm{C}$ selama $1 \times 24$ jam. 


\section{Pengamatan dan Pengukuran}

Pengamatan dilakukan setelah 1×24 jam masa inkubasi. Daerah bening merupakan petunjuk kepekaan bakteri terhadap antibiotik atau bahan antibakteri lainnya yang digunakan sebagai bahan uji yang dinyatakan dengan lebar diameter zona hambat (Vandepitte et al., 2005). Diameter zona hambat diukur dalam satuan milimeter ( $\mathrm{mm}$ ) menggunakan mistar berskala dengan cara diameter keseluruhan dikurangi diameter sumuran $7 \mathrm{~mm}$. Kemudian diameter zona hambat tersebut dikategorikan kekuatan daya antibakterinya berdasarkan penggolongan Davis \& Stout (1971).

\section{Hasil dan Pembahasan}

\section{Aktivitas Antibakteri}

Hasil uji aktivitas antibakteri yang menggunakan metode difusi agar (difusi Kirby dan Bauer yang dimodifikasi) dengan cara sumuran dan hasil pengukuran rata-rata diameter zona hambat komposit Ag - tulang ikan cakalang terhadap Staphylococcus aureus dideskripsikan pada Gambar 4 dan Tabel 1. Gambar 4 menunjukan pada kedua media pertumbuhan bakteri memiliki zona bening baik pada sumuran yang ditetesi ketiga sampel yaitu perbandingan 5:1 (A1), 4:2 (A2), 3:3 (A3) dan sumuran yang ditetesi kontrol positif. Sedangkan, pada sumuran yang ditetesi oleh kontrol negatif tidak menunjukkan adanya zona bening.

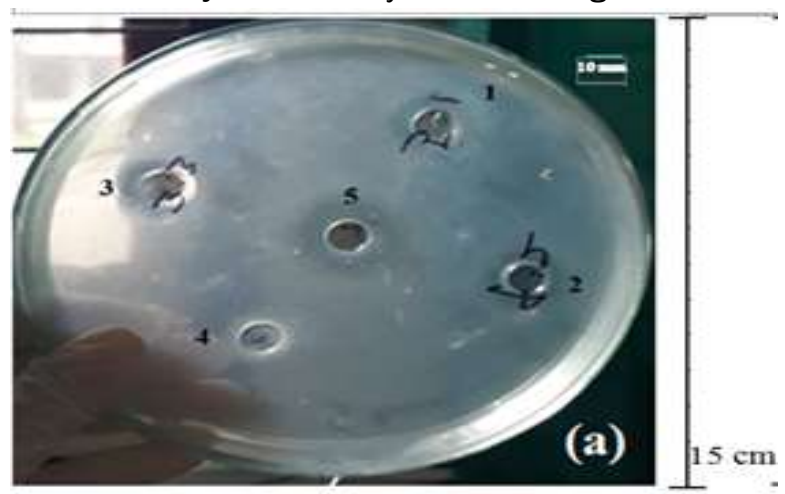

Gambar Hasil Uji Aktivitas Antibakteri Komposit Ag Tulang Ikan Cakalang dengan Lama Waktu

Pencampuran 1 Jam Terhadap Bakteri S. aureus

Keterangan gambar :

$1=$ Perbandingan $5: 1$ (A1)

2 = Perbandingan $4: 2$ (A2)

3 = Perbandingan $3: 3$ (A3)

$4=$ Kontrol negatif (PBS)

$5=$ Kontrol positif (Ciprofloxacin $50 \mu g / 50 \mu l$ )

Hal ini menunjukkan bahwa ketiga sampel yang digunakan memiliki efek sebagai antibakteri sama seperti antibiotik ciprofloxacin yaitu kontrol positif yang digunakan, sedangkan PBS yang digunakan sebagai kontrol negatif tidak memiliki efek sebagai antibakteri karena bakteri dapat tumbuh pada sumuran di kedua media pertumbuhan bakteri tersebut.

Menurut Davis \& Stout (1971), kriteria kekuatan daya antibakteri sebagai berikut : diameter zona hambat $5 \mathrm{~mm}$ atau kurang dikategorikan lemah, zona hambat $5-10 \mathrm{~mm}$ dikategorikan sedang, zona hambat 10 - $20 \mathrm{~mm}$ dikategorikan kuat dan zona hambat $20 \mathrm{~mm}$ atau lebih dikategorikan sangat kuat.

Tabel 1 menunjukkan bahwa semakin besar diameter zona hambat pertumbuhan bakteri maka semakin kuat daya antibakteri dari sampel yang digunakan. Ketiga sampel (A1, A2, dan A3) yang digunakan menunjukkan diameter zona hambat yang lebih besar terhadap bakteri Gram positif Staphylococcus aureus.

Tabel 1. Hasil Pengukuran Rata - Rata Diameter Zona Hambat Komposit Ag - Tulang Ikan Cakalang dengan Lama Waktu Pencampuran 1 Jam Terhadap Pertumbuhan Bakteri S. aureus.

Berdasarkan kriteria - kriteria Davis \& Stout Rata - Rata Diameter Zona Hambat Pertumbuhan

Konsentrasi Bakteri ( $\mathrm{mm})$

\section{S. aureus}

\section{A1}

\section{5}

A2

A3

kontrol $(+)$

kontrol (-)

0

(1971), maka pada komposit Ag - tulang ikan cakalang dengan lama waktu pencampuran 1 jam, perbandingan paling efektif untuk menghambat bakteri S. aureus adalah perbandingan 4:2 . Sebab, pada perbandingan tersebut daya antibakterinya dikategorikan sangat kuat untuk menimbulkan zona hambatan yang besar.

Dalam penelitian ini, aktivitas komposit Ag tulang ikan cakalang dengan lama waktu pencampuran 1 jam dalam menghambat pertumbuhan bakteri Gram positif S. aureus sangat baik Data studi lainnya juga menunjukkan hasil yang sama, dimana material hidroksiapatit dari tulang paha sapi betina yang mengandung perak (Nirmala et al., 2011) dan kalsium fosfat yang mengandung perak (Ando et al., 2010) menunjukkan aktivitas antibakteri yang lebih baik terhadap bakteri Gram positif dibandingkan Gram negatif.

Hal ini disebabkan karena dinding sel bakteri Gram positif terdiri atas beberapa lapisan peptidoglikan yang membentuk struktur yang tebal dan kaku serta mengandung substansi dinding sel yang disebut asam teikoat, sedangkan dinding sel bakteri Gram negatif hanya mengandung lapisan tipis peptidoglikan tetapi dikelilingi oleh membran lipid kedua yang mengandung lipopolisakarida dan lipoprotein. Dinding sel Gram positif biasanya tidak memiliki membran sel bagian luar yang ditemukan pada bakteri Gram negatif. Membran luar melindungi bakteri Gram negatif dari beberapa antibiotik dan agen antibakteri, yang biasanya 
merusak membran dalam atau dinding sel (peptidoglikan) (Tortora et al., 1998).

Kontrol negatif yang digunakan adalah PBS yang menunjukkan tidak adanya zona hambat. Hal ini mengindikasikan bahwa kontrol yang digunakan tidak berpengaruh pada uji antibakteri. Antibiotik yang digunakan sebagai pembanding atau kontrol positif adalah Ciprofloxacin.

Menurut Jawetz et al (2005), Ciprofloxacin memiliki efek antibakteri yang besar (spektrum luas). Hasil penelitian menunjukkan bahwa diameter zona hambat yang dibentuk oleh Ciprofloxacin lebih besar pada bakteri Gram positif S. aureus (28,33 $\mathrm{mm})$. Mekanisme kerjanya dengan menghambat topoisomerase II (= DNA girase) dan topoisomerase VI pada bakteri.

\section{Kesimpulan}

Hasil penelitian menunjukkan adanya aktivitas antibakteri pada ketiga perbandingan komposit Ag tulang ikan cakalang yang digunakan terhadap bakteri S. aureus, dengan perbandingan paling efektif untuk menghambat bakteri Staphylococcus aureus adalah pada komposit dengan lama waktu pencampuran 1 jam yaitu perbandingan 4:2 dengan diameter zona hambat sebesar $25 \mathrm{~mm}$.

\section{Daftar Pustaka}

Ando, Y., Miyamoto, H., Noda, I., Sakurai, N., Akiyama, T., Yonekura, Y., Shimazaki, T., Miyazaki, M., Mawatari, M., and Hotokebuchi, T. 2010. Calcium Phosphate Coating Containing Silver Shows High Antibacterial Activity and Low Cytotoxicity and Inhibits Bacterial Adhesion. Materials Science and Engineering: C. 30 : 175-180.

Davis, W.W and Stout, T.R. 1971. Disc Plate Methods of Microbiological Antibiotic Assay. Microbiology. 22 : 659 - 665.

Djide dan Sartini. 2008. Dasar-Dasar Mikrobiologi Farmasi. Lephas, Makasar.

Jawetz, E., Melnick, J.L., and Adelberg, F.A. 2005. Mikrobiologi Kedokteran. Salemba Medika, Jakarta.

Kim, J.S., Kuk, E., Yu, K.N., Kim, J.S., Park, S.J., Lee, H.J., Kim, S.H., Park, Y.K., Park, Y.H., Hwang, C.Y., Kim, Y.K., Lee, Y.S., Jeong, D.H., \& Cho, M.H. 2007. Antimicrobial effects of silver nanoparticles. Nanomedicine: Nanotechnology, Biology and Medicine. 3 : 95 - 101.

Lay, B.W. 1994. Analisis Mikroba di Laboratorium. Edisi 1. Raja Grafindo Persada, Jakarta.

Lay, B.W and Hastowo, S. 1992. Mikrobiologi. Institut Pertanian Bogor, Bogor.

Mpila, D., Fatimawali., dan Wiyono, W.I. 2012. Uji Aktivitas Antibakteri Ekstrak Etanol Daun Mayana (Coleus Atropurpureus [L] Benth) Terhadap Staphylococcus Aureus, Escherichia Coli Dan Pseudomonas Aeruginosa Secara InVitro. Pharmacon. 1: 15 - 16.

Nirmala, R., Sheikh, F.A., Kanjwal, M.A., Lee, J.H., Park, S.J., Navamathavan, R., \& Kim, H.Y. 2011. Synthesis and characterization of bovine femur bone hydroxyapatite containing silver nanoparticles for the biomedical applications. Journal of Nanoparticle Research. 13 : 1917 1927.

Piccirillo, C., Pinto,R.A., Tobaldi,D.M., Pullar,R.C., Labrincha,J.A., Pintado,M.M.E., and Castro, P.M.L. 2014. Light induced antibacterial activity and photocatalytic properties of $\mathrm{Ag} / \mathrm{Ag}_{3} \mathrm{PO}_{4}$ based material of marine origin. Journal of Photochemistry and Photobiology A: Chemistry. $296: 40-47$.

Stanić, V., Janaćković, D., Dimitrijević, S., Tanasković, S.B., Mitrić, M., Pavlović, M.S., Krstić, A., Jovanović, D., and Raičević, S. 2011. Synthesis of Antimicrobial Monophase SilverDoped Hydroxyapatite Nanopowder for Bone Tissue Engineering. Applied Surface Science. 257 : 4510 - 4518.

Tortora, G.J., Funke, B.R., and Case, C.L. 1998. Microbiology an introduction. 6th edn. California: Benjamin/Cummings Publishing Company.

Vandepitte, V.J., Engbaek, K., Rohner, P., Piot, P., and Heuck, C.C. 2005. Prosedur Laboratorium Dasar untuk Bakteriologis Klinis. Edisi 2. Buku Kedokteran EGC, Jakarta. 